\title{
Teachers' Beliefs on Technological Fusion in Teaching ESL Students
}

\author{
Kulwant Kaur Kartar Singh, Hamidah Yamat, Wahiza Wahi \\ Universiti Kebangsaan Malaysia, Bandar Baru Bangi, Malaysia \\ Email: kulwant@iium.edu.my, hamidah_yamat@ukm.edu.my
}

How to cite this paper: Singh, K. K. K., Yamat, H., \& Wahi, W. (2018). Teachers' Beliefs on Technological Fusion in Teaching ESL Students. Creative Education, 9, 2125-2136. https://doi.org/10.4236/ce.2018.914154

Received: August 16, 2018

Accepted: October 23, 2018

Published: October 26, 2018

Copyright $\odot 2018$ by authors and Scientific Research Publishing Inc. This work is licensed under the Creative Commons Attribution International License (CC BY 4.0).

http://creativecommons.org/licenses/by/4.0/

\begin{abstract}
Studies on the effectiveness of technology have shown that it enhances students in language learning and helps gain their involvement. Nevertheless, there is still resistance among teachers in using technology in the language classrooms due to the rapid advancements of technology. The aim of the study reported in this article was therefore to gather testimonial insights on teachers' beliefs about technology and its fusion to illuminate how English as a second language (ESL) teaching and learning is eased and made meaningful in classrooms. This paper reports on a case study that looks into primary school teachers' beliefs on technological fusion in teaching ESL students. Data were collected from three teachers of different teaching experiences through interviews and observations and themes were generated through constant comparative and thematic analysis; assisted with the use of ATLAS ti.7 software. Findings indicate that despite positive beliefs that the fusion of technology assists language teaching and learning, not all teachers embrace technology in their classrooms as schools especially in rural areas lack facilities to aid the use of technology. This study implies that there is a need to equip all schools with devices and equipment that aid the fusion of technology in language teaching.
\end{abstract}

\section{Keywords}

Teachers' Beliefs, Technological Fusion, Teaching English, ESL Students, Primary School

\section{Introduction}

With the widespread adoption of technology in the 21st century, English language teaching and learning has become more challenging. Students of this era demand stimulating activities using technology as studies worldwide have shown that the integration of technology into classrooms has been found to be provid- 
ing a relaxing environment, guiding students to organise, explain and clarify, arousing students' interest, maintaining students' interest and attention, motivating, providing positive reinforcement, and improving the teaching and learning quality (Arkan, Taser, \& Sarac-Suzer, 2008; Aydin, Bayram, Canidar, Cetin, Ergunay, Ozdem, \& Tunc, 2009; Cheung, 2006; Dincer, 2013; Maszkowska, 2017; Mutmainna, 2016; El Said Abdul Fattah, 2016; Aydin, 2016; Shishavan \& Sadeghi, 2009; Yu-Hsin, 1999). Teachers of the 21st century have therefore improved their personal and professional use of computer; and used technology for classroom communicative tasks as well as administrative purposes (Van Braak, Tondeur, \& Valcke, 2004).

However, studies have also shown that teachers: hesitate to use technology in the classroom as technology tools and resources are constantly changing (Straub, 2009), lack of relevant knowledge on technology (Lawless \& Pellegrino, 2007), have low-self-efficacy (Mueller, Wood, Willoughby, Ross, \& Specht, 2008), and have existing belief systems regarding technology (Hew \& Brush, 2007; Subramaniam, 2007). In Malaysia's ESL context, inadequate instructional aids and materials that do not meet the demands of the students have been found to be factors that contribute to low proficiency among most primary school students (Hassan \& Selamat, 2002) as well as classrooms that are not well-equipped with computers and thus unsuitable for technology based lessons (Hamzah, Ismail, \& Embi, 2009).

Hence, The Malaysian Ministry of Education (MOE) introduced a curriculum reform known as the Standard Curriculum for Primary Schools (SCPS) or in Malay, Kurikulum Standard Sekolah Rendah (KSSR) in 2011. The SCPS was introduced to overcome certain shortcomings within the older system, the Integrated Primary School Curriculum (IPSC) or Kurikulum Bersepadu Sekolah Rendah (KBSR). With this new restructured and improved curriculum, the MOE strives to address the issue of improving the standard of English language among Malaysian students and to provide primary school children with the necessary knowledge, skills and also the values to face and overcome the challenges of the current times. In this fast paced progressive world, what worked very well in 1983 under the IPSC system is just not good enough today. In other words, the reform of the education system and curriculum was from one that has very academic or performance based objectives to one that includes the integration or fusion of technology in the learning environment with the objective to provide the skills needed to survive in the technological demanding world. It is designed to enhance and embrace the fusion of science and technology in learning to ensure that children; including children at primary school level; can perform successfully on a global platform. Hence, the teaching materials employed in current classrooms are technological based to cater to the needs of the 21st century students and in helping them to increase their English language proficiency (Ahamed \& Safinas, 2016). Meanwhile, Bakar, Latif, \& Ya'acob (2017) recommends that English language teachers change their teaching techniques to meet the needs of contemporary students by fusing technology with their existing 
materials to enhance the teaching and learning of English. In addition, as little attention has been given to English language teaching at the primary level (Juliana, 2010), investigation at primary level is essential as it is at this level that students attain their basic proficiency.

In line with the problem discussed above and the gap in research, it is significant to investigate: 1) what ESL teachers in primary schools in Malaysia believe about the use of technology; and 2) how technological fusion is evident in their teaching and learning practices. Thus this research sets forth to find answers to the questions:

1) What are the English language teachers' beliefs about technological fusion in teaching the ESL primary school students?

2) How do the English language teachers integrate technology in their classrooms?

\section{Literature Review}

Students' lack of motivation and interest is one of the setbacks in learning the English language (Baker, Do, \& Mailand, 2015). The instructional aids and methodology teachers use to teach English in the ESL classroom play a major role to sustain students' attention and to evoke their interest. Varalakshmi (2013) stated that the use of outdated methods among teachers in teaching the English language in Malaysia is worrying. Thus, suitable techniques and methods need to be applied by teachers in primary schools as basic exposure to the English language is received at this level. There is a need for teachers to equip themselves with adequate knowledge pertaining to pedagogy and subject matter besides having positive beliefs of themselves, teaching and learning and the students. Teachers' pedagogical knowledge has great significance to teaching as it reflects their knowledge and its dissemination in the classroom which inadvertently affect students' proficiency. Thus, integration of different types of electronic media resources is necessary to supplement the pedagogical methods among teachers to evoke these students interest in learning the English language.

An array of knowledge and skills also need to be adopted by teachers to meet the expectations and challenges of the current education era. Knowledge gained during pre-service education is insufficient for teachers. In fact they are required to keep improving and upgrading themselves to stay abreast of global competition. An environment using the electronic media that is inviting to students of this new era encourages students to be more active in the learning process which in turn makes the process more effective (Baker, Do, \& Mailand, 2015). In their research, it was found that creating an environment that is appealing to the students is important to nurture learning. This is supported by (Boles, 2011) who stressed that interaction and motivation among students need to be fostered using technology due to its availability and accessibility to technological resources now more than before. Another study by Parvin \& Salam (2015). showed a significant change in the classroom environment when technology was used in the 
classes as there was excitement, curiosity, attentiveness and the students' questioning skills improved compared to a traditional teaching style.

According to (Eaton, 2010), the language classrooms today are not the same as the mid to late 20th century as the focus is more on communication now rather than memorization and rote learning. Thus, the use of technology and people skills is vital tools that need to be incorporated into the curriculum to ensure that children can perform successfully on a global platform. They need to be equipped not only with the necessary knowledge and skills but also with the strength of character and leadership qualities to be successful. In this new curriculum, there are set standards of learning that children have to achieve at the different levels of their schooling. This means that when children complete a particular level of schooling, they are expected to have achieved a pre-set standard of knowledge, skills and values. At specific times at each level, these learning standards will be measured to ensure that no child gets left behind. If a child fails to meet the required standard, the teacher is required to do more revision activities with the child until he or she eventually achieves the required standard.

These indicate the different learning environment due to technological fusion. Teachers now need to have technological content knowledge too apart from the pedagogical and content knowledge. The integration of technology into the teaching and learning processes was taken into consideration as it was deemed necessary to develop content and pedagogical knowledge needed to improve classroom practices (Graham, 2011). Thus, the complexity of literacy related to content, pedagogy and technology caused researchers to use Technological Pedagogical Content Knowledge (TPACK) which represents transformation into the new forms to maximise effectiveness of technology in teaching.

However, the problem in Malaysian schools is the lack of computer-based facilities as the classrooms are not well-equipped with computers and thus deter efforts of technological fusion (Hamzah, Ismail, \& Embi, 2009; Roehrig, Kruse, \& Kern, 2007; Somekh, 2008) also agreed with this notion as challenges teachers encounter in schools serve as an obstacle to use technology in the classroom. Another problem faced in the integration of technology as stated by (Orlando, 2014) is the unwillingness to use technology in the classroom by some teachers as they fear its use. (Hazita, 2016) notes that the universal challenges of English language education in primary schools in Malaysia entail restricted computer literacy, insufficient instructional design, technical malfunctions, inefficient ICT infrastructure and hardware which resulted teachers' resistance to adopt and integrate technology in their classrooms.

\section{Methodology}

To set forth better insights of the teachers' use of technology, this study undertook a qualitative stance. It aimed to examine primary school teachers' beliefs about the use of technology in teaching English in the ESL classroom. Primary school teachers were chosen to participate in this study as it is at the primary 
level that students attain basic exposure to the English language before it is developed for further acquisition and learning. Thus, the role of the teachers at this level is significant. Furthermore, an exploration of the primary school teachers' beliefs about the use of technology could disclose the most essential impact of language teaching.

This study used purposive sampling procedure and three teachers categorised as veteran teacher (VT), a teacher with 15 years of experience, an experienced teacher (ET), a teacher having 6 years of teaching experience and a novice teacher (NT) who had taught for one year were identified to participate in the study. The research site was a low-achievement rural school in Selangor Darul Ehsan which comprised a majority of less-proficient English language students. It had a population of 756 students and consisted of $70 \%$ Malay students, $26 \%$ Indian students and $4 \%$ Chinese students. The students of the participants ranged from 8 to 11 years old and were students who learn the English language as a second language. These students are non-native speakers and their primary language is the Malay language. As they lacked exposure outside school, the English language is more like a foreign language than a second language to them. However, as the English is learnt as a second language in Malaysian schools, the students learn the English language as a second language.

The teachers were chosen as their different knowledge and experiences would add a wholesome perspective to the findings. The instruments used in this study were interviews and observations. Interviews were carried out to find out what the teachers' beliefs about the use of technology are in the classroom. Meanwhile, the observation method was used to investigate if technology was integrated in their lessons. Interviews before and after class were administered to obtain the data and classroom observations were videotaped to record what transpired in the classroom so that a description of classroom interaction could be done intensely and empirically. Each teacher was interviewed 6 times and three observations per participant were carried out. Data collected from the interviews and observations were then coded and analysed using (Strauss \& Corbin, 2015) grounded theory approach which involved a constant comparative process (Silverman, 2010).

In order to identify themes and patterns of the coded data, thematic analysis by (Braun \& Clarke, 2006) was used in this study and ATLAS. Version 7 software was utilized to manage data. Three experienced teachers pilot tested the interview questions and observation checklist of the study to ensure validity. Member checking process was also administered to ascertain the accuracy of the transcription. Meanwhile, a Cohen Kappa Reliability Test administered by two experts in the ESL field showed an almost perfect agreement. Before you begin to format your paper, first write and save the content as a separate text file. Keep your text and graphic files separate until after the text has been formatted and styled. Do not use hard tabs, and limit use of hard returns to only one return at the end of a paragraph. Do not add any kind of pagination anywhere in the pa- 
per. Do not number text heads-the template will do that for you.

Finally, complete content and organizational editing before formatting. Please take note of the following items when proofreading spelling and grammar:

\section{Findings}

1) The English language teachers' beliefs about the use of technology in their classroom

The findings revealed that the teachers unanimously believed that technology should be integrated into the teaching and learning process. The veteran teacher (VT) believed that it is important to use technology to teach English in the ESL classroom as it assists in gaining her students' attention and they will not dislike learning the English language. Despite having a penchant for traditional teaching style and teaching grammar, the VT prepares technology-based tasks when planning additional activities for her students. According to her, students are no longer attracted to the traditional chalk and talk method. She stressed that she has to resort to using modern techniques by using laptop and LCD screen to project pictures and images as she finds her students more motivated to learn and lessons are delivered more effectively. She added that there is excitement among students when she uses video recorders, players and speakers in the classroom as students participate enthusiastically and would attempt to speak or read actively. She stated further that her current students are different from students she had taught ten years ago and are more computer savvy. She explained:

They are not proficient in English, but they are advanced in sourcing for sources from the internet. Yah, they are quite... they want something creative and innovative you know and like err... cyber kind of things you know, everything to do, to do with computers you know, internet, you tube.

Thus, as the VT's students have a penchant for technology, the reading corner of her classroom is enriched with sources from the internet. She downloads online materials, laminates and exhibits them on the noticeboard in the classroom. Knowledge is obtained from stories, verbs, idioms and by viewing the colourful images displayed and students learn subconsciously as they walk around the classroom. She strongly recommends this technique stressing on the importance of teachers using the internet to source materials for reading corners of their classrooms.

Similarly, the experienced teacher (ET) professed that in her classroom, she uses resources from the internet and prepares materials that she sources from online websites to supplement the text book. She echoed the VT's statement and stated that merely reading from text books and using the chalk and talk method is less effective as students of the 21st century are easily bored with regular classroom activities due to exposure to entertainment outside school. She lamented:

Hence, they need something as what they get outside the classroom to gain their interest and to motivate them to learn the language. 
However, she expressed her disappointment about being unfortunate having to teach in schools devoid of teaching facilities. Both the schools that she taught, her former school and the school she is currently teaching have insufficient facilities to assist teachers in the ESL classroom as there is a need for more resources and because internet connection and power point facilities are dissatisfactory. This thwarts them from using lap tops and the electronic media in the classroom. In fact, according to the ET, the teachers have to spend time taking their students to the computer room which is a hassle as it wastes time. Even though during the observation, there was no evidence of incorporation of technology in her lessons, she admitted obtaining additional resources from the internet:

Ok, mmm... in terms of planning my teaching, I do refer to the textbook as a guideline, but for err the materials, I take it you know from other resources. You know, I find them on the internet or I find them from other workbooks yah. I use it but my main focus is on the textbook. Only thing, the materials and techniques might differ.

She justified not using technology in her classroom by stressing that her school is short of computer based facilities and sharing one computer lab with other teachers is a hassle. Furthermore, she added that taking more than 30 students to the computer lab is time-consuming.

Meanwhile, the novice teacher (NT) urged that there should be a variety of techniques and strategies when teaching English and the activities should not be limited to books but there should be an integration of movies and experiments. Limited source of materials such as printed materials cause boredom among students of the new millennium as they demand variety from other sources. She reported:

Err... they learn through maybe social media, face book, err... using the computer itself and television, watching movies, it really helps them and then in the classroom as well.

The NT shared that her students' knowledge is limited and they lacked proficiency. However, when they are engaged in computer based games, they perform well. She believes that learning is influenced by students' background knowledge, so it is necessary to be sensitive to their needs and to plan lessons based on technology. She added that as her students prefer activities based on songs and videos, she prepares her lesson plan that caters to their needs. As her school has limited technology-based facilities, she admitted that she carries her lap top together with speakers to class. Besides, taking her students to the computer lab will only use up the time allocated for teaching and learning:

We have makmal komputer [computer lab] but I do not use it. I only bring the lap top and the speaker to my class because it's just, I want to use it for like ten minutes, that's it. So, I just ask them to sit on the floor because there are not many of them. So, I open my laptop, speaker, open the video, yah.

2) Technological fusion in the English teachers' classrooms

Surprisingly during classroom observation, it was discovered that only the VT incorporated the use of technology in her lessons. In fact, she was observed using 
the LCD projector for her lessons. As was witnessed in her classroom, to complement a reading comprehension task, a picture of a camp-site was projected on the LCD screen to encourage sentence construction activity to prepare them for the final examination. Her students were also seen to participate in a chain sentence construction activity based on a picture shown on the screen. This was followed by a peer-error correction activity in which her students were instructed to identify and correct errors made in the sentences constructed by their peers. In another observation, a song entitled "Rhythm of the Falling Rain" was played for the students after identifying adjectives in the newspaper and they had to identify adjectives in the lyrics of the song:

I want to play a song for you all. Shh! Attention. I want to play a song. Listen to the song carefully. Then, I will ask questions from that song.

The VT conducted all the three lessons in the computer lab. This is in contrast with the ET and the NT's lessons which had no incorporation of technology. The VT believed that the use of technology is vital in her classroom since the students of this millennium demand creative and innovative activities. She did not deny using the traditional method of teaching but to add a variety to her repertoire of teaching methods, the use of technology complements her lessons. Students according to her prefer modern techniques compared to the traditional methods of teaching. Thus, in order to provide a positive learning experience for her students and to deliver knowledge effectively, she uses modern techniques in her classroom. What transpired in her classroom reflected her beliefs about the use of technology.

There was no integration of technology in the ET and NT's classrooms. While the ET depended on the textbook occasionally, the NT depended on it entirely. Additional materials were used in the ET's classroom and her students were encouraged to be creative in producing a scrap book on sea creatures and to create figurines using plasticine. There was collaboration among the students as they discussed and made decisions during the lessons. The NT however gave more emphasis to grammar and reading activities obtained from the textbook and there were insufficient supplementary materials that complemented the activities from the text book. Define abbreviations and acronyms the first time they are used in the text, even after they have been defined in the abstract. Abbreviations such as IEEE, SI, MKS, CGS, sc, dc, and rms do not have to be defined. Do not use abbreviations in the title or heads unless they are unavoidable.

\section{Discussion}

Teachers who have students of the new era have to plan their classroom activities that could arouse their students' interest to meet their needs. Thus, it is apparent that teachers need to pave ways to identify the latest techniques that apply in the teaching and learning process. One of the ways to reach students of the new millennium is through technology as shared by the teachers in this study emphasizing on the use of technology-related materials and use of LCD screens which project colourful pictures, video recorders, players, speakers, songs and 
movies. However, the set-back faced by the teachers is insufficient facilities to aid teaching and learning using technology in the classroom.

The NT concurs with the ET about the time taken whenever they take their students to the computer lab. As her school lacked computer-based facilities, she resorts to taking her laptop and speakers to the classroom when there is a need. This is supported by (Hamzah, Ismail, \& Embi, 2009) who stressed that insufficient computer-based facilities in Malaysian classrooms is a hindrance to technology-aided teaching and learning process.

Another problem faced by the NT is insufficient time to prepare materials due to non-teaching responsibilities. This was obvious in the classroom during the observation as she had to miss 25 minutes of her lesson to attend to computer lab matters. Ali (2002) revealed that NT in Malaysian schools are given more responsibilities compared to the ET. That was one of the factors stressed by the NT which inhibits her from producing additional materials to supplement the use of text book. This finding is in accordance with (Gordon, 1991) findings that stressed on the problems faced by novice teachers in obtaining instructional materials from other sources and also in planning and organizing activities in the classroom. This was supported by Carpenter (2002) as he stressed on the struggles novice teachers have to encounter due to lack of adequate materials and non-teaching duties.

It is also discovered that despite the known fact that veteran teachers are not as well-versed in the use of technology, it was surprising to find that the VT used technology in her lessons compared to the ET and VT. It is a surprising fact that the younger teachers did not integrate the use of technology into their lessons even though they are most often thought to be better in the use of technology compared to their older counterparts. Thus, it can be concluded that veteran teachers do make attempts to use technology in the classrooms and do adopt technology in their teaching. It is evident that education has changed the perception of most teachers about teaching using technology positively. Teachers need to integrate technology in their ESL classroom to encourage the students of this current century who prefer fun learning and interactive technology-based activities. However, there is still unwillingness to integrate technology when planning lessons among some teachers (Orlando, 2014). Teachers need to be aware of the importance of technology use and need to be encouraged to use it. Therefore, it is of utmost importance for the Ministry of Education to encourage teachers who are hesitant to use technology and also to coax them to use the current technology-based methods of teaching due to the pervasiveness of technology now compared to the past. Use either SI (MKS) or CGS as primary units. (SI units are encouraged.) English units may be used as secondary units (in parentheses). An exception would be the use of English units as identifiers in trade, such as "3.5-inch disk drive".

\section{Conclusion}

There was a surprising revelation in this research related to the use of technology 
among primary school teachers. Evidently, the VT despite being the oldest among all the teachers decided to use technology in her teaching and learning process. Even though previously younger teachers were known to be well-versed with technology, to meet the demands of the current education reform, the veteran teachers have taken the leap towards technology-based teaching and are just as competent as their younger colleagues. This implies that age is no barrier in adopting technology but teachers need to employ appropriate skills and have the passion to teach in order to determine an effective ESL classroom.

This study notes that despite being effective, the use of technology in the primary classroom lab causes students to get carried away as these young students easily get distracted by the seating arrangement and the equipment there. Nevertheless, the use of technology in English language teaching will not only strengthen lessons further but will also allow students to explore and attain knowledge through a variety of approaches. This can lead to an effective and beneficial teaching and learning atmosphere. This study also implies that inadequate facilities and limited resources in the classrooms deter teachers from using technology to teach. Classrooms which are unequipped with computers and sharing one computer lab prevent the teachers from using technology. Thus, in order to meet the objectives of the Malaysian Education Blueprint (2013-2015) and to meet the requirement of the 21 st century education, this study recommends that schools need to be well-equipped with excellent facilities.

\section{Conflicts of Interest}

The authors declare no conflicts of interest regarding the publication of this paper.

\section{References}

Ahamed, A. B., \& Safinas, R. N. (2016). The Principles Adopted in Designing the Webcomics to Assist Lower Secondary Students with Reading Comprehension. International Journal of Academic Research in Business and Social Sciences, 6, 708-721.

Ali, M. S. (2002). Professional Development of ESL Teachers in Primary Schools. TIGAENF Journal Pendidikan IPBA, 2, 43-62.

Arkan, A., Taser, D., \& Sarac-Suzer, H.S. (2008). The Effective English Language Teacher from the Perspectives of Turkish Preparatory School Students. Education and Science, 33, 42-51.

Aydin, B., Bayram, F., Canidar, B., Cetin, G., Ergunay, O., Ozdem, Z., \& Tunc, B. (2009). Views of English Language Teachers on the Affective Domain of Language Teaching in Turkey. Anadolu University Journal of Social Sciences, 9, 263-280.

Aydin, S. (2016). The Use of Blogs in Learning English as a Foreign Language. Meylana International Journal of Education, 4, 244-259.

Bakar, N. A., Latif, H., \& Ya'acob, A. (2017). Fusion of Technology with Language Learning: Blog Community. The Southeast Asian Journal of English Language Studies, 23, 200-211. https://doi.org/10.17576/3L-2017-2304-15

Baker, R., Do, D. M., \& Mailand, S. (2015). The Use of Technology to Enhance English Language (ESL) Teaching: An Interactive Qualifying Project Report. Faculty of Worce- 
ster, Polytechnic Institute.

Boles, S. R. (2011). Using Technology in the Classroom. Science Scope, 34, 39.

Braun, V., \& Clarke, V. (2006). Using Thematic Analysis in Psychology. Qualitative Research in Psychology, 3, 77-101.

Carpenter, J. L. (2002). Struggles, Strategies, Settlements and Survival: Case Studies of Three Beginning Teachers. PhD Thesis.

Cheung, H. Y. (2006). The Measurement of Teacher Efficacy: Hong Kong Primary In-Service Teachers. Journal of Education for Teaching: International Research and Pedagogy, 32, 435-451. https://doi.org/10.1080/02607470600982134

Dincer, A. (2013). Common Characteristics of an Effective English Language Teacher. The International Journal of Educational Researchers, 4, 1-8.

Eaton, S. E. (2010). Global Trends in Language Learning in the Twenty-First Century. Calgary: Onate Press.

El Said Abdul Fattah, S. F. (2016). The Effectiveness of Using Blogs as an Independent Learning Tool to Develop Reading Skills for University Students. Journal of Education and Practice, 7, 65-73.

Gordon, S. P. (1991). How to Help Beginning Teachers Succeed. Alexandria, VA: Association for Supervision and Curriculum Development.

Graham, C. R. (2011). Theoretical Considerations for Understanding Technological Pedagogical Content Knowledge (TPACK). Computers \& Education, 57, 1953-1960.

https://doi.org/10.1016/j.compedu.2011.04.010

Hamzah, M. I., Ismail, A., \& Embi, M. A. (2009). The Impact of Technology Change in Malaysian Smartschools on Islamic Education Teachers and Students. World Academy of Science, Engineeringand Technology 49.

Hassan, F., \& Selamat, N. F. (2002). Why Aren't Students Proficient in ESL? The Teachers' Perspective. Universiti Putra Malaysia.

Hazita, A. (2016). Implementation and Challenges of English Language Education Reform in Malaysian Primary Schools. 3L: The Southeast Asian Journal of English Language Studies, 22, 65-78. https://doi.org/10.17576/3L-2016-2203-05

Hew, K. F., \& Brush, T. (2007). Integrating Technology into K-12 Teaching and Learning: Current Knowledge Gaps and Recommendations for Future Research. Educational Technology Research and Development, 55, 223-252. https://doi.org/10.1007/s11423-006-9022-5

Juliana, O. (2010). Teachers' Instructional Practices in Teaching English at Malaysian Primary Schools. http://eprints.um.edu.my/11281/1/1112.pdf

Lawless, K. A., \& Pellegrino, J. W. (2007). Professional Development in Integrating Technology into Teaching and Learning: Knowns, Unknowns, and Ways to Pursue Better Questions and Answers. Review of Educational Research, 77, 575-614. https://doi.org/10.3102/0034654307309921

Maszkowska, N. (2017). The Use of Technology in English Language Teaching. English in Interdisciplinary Context of Life-Long Education. Torun: Nicolaus Copernicus University Poland Pub..

Mueller, J., Wood, E., Willoughby, T., Ross, C., \& Specht, J. (2008). Identifying Discriminating Variables between Teachers Who Fully Integrate Computers and Teachers with Limited Integration. Computers and Education, 51, 1523-1537. https://doi.org/10.1016/j.compedu.2008.02.003

Mutmainna, M. (2016) Implementing Blogs as a Learning Tool in ASIAN EFL/ESL 
Learning Context. BRAC University Journal, XI, 25-35

Orlando, J. (2014). Veteran Teachers and Technology: Change Fatigue and Knowledge Insecurity Influence Practice. Teachers and Teaching Journal, 20, 427-439.

Parvin, R. H., \& Salam, S. F. (2015). The Effectiveness of Using Technology in English Language Classrooms in Government Primary Schools in Bangladesh. FIRE: Forum for International Research in Education, 2, 47-59.

Roehrig, G. H., Kruse, R. A., \& Kern, A. (2007). Teacher and School Characteristics and Their Influence on Curriculum Implementation. Journal of Research in Science Teaching, 44, 883-907. https://doi.org/10.1002/tea.20180

Shishavan, H. B., \& Sadeghi, K. (2009). Characteristics of an Effective English Language Teacher as Perceived by Iranian Teachers and Learners of English. English Language Teaching Journal, 2, 130-143.

Silverman, D. (2010). Doing Qualitative Research (3rd ed.). London: Sage Publications.

Somekh, B. (2008). Factors Affecting Teachers' Pedagogical Adoption of ICT. In J. Voogt, \& G. Knezek (Eds.), International Handbook of Information Technology in Primary and Secondary Education (pp. 449-460). New York, NY: Springer. https://doi.org/10.1007/978-0-387-73315-9_27

Straub, E. (2009). Understanding Technology Adoption: Theory and Future Directions for Informal Learning. Review of Educational Research, 79, 625-649. https://doi.org/10.3102/0034654308325896

Strauss \& Corbin (2015). Basics of Qualitative Research: Techniques and Procedures for Developing Grounded Theory. Thousand Oaks, CA: Sage Publications.

Subramaniam, K. (2007). Teachers' Mindsets and the Integration of Computer Technology. British Journal of Educational Technology, 38, 1056-1071. https://doi.org/10.1111/j.1467-8535.2006.00693.x

Van Braak, J., Tondeur, J., \& Valcke, M. (2004). Explaining Different Types of Computer Use among Primary School Teachers. European Journal of Psychology of Education, 19, 407-422. https://doi.org/10.1007/BF03173218

Varalakshmi, G. (2013). Deterioration of English Standards: A Case Study. Journal of ELT and Poetry, 1, 68-72.

Yu-Hsin, T. (1999). Examining Student Perceptions of the Ideal English Language Instructor. HwaKang Journal of TEFL, 5, 1-26. 